\title{
Eğitimde Ölçme ve Değerlendirme Dersinde Başarıyı Etkileyen Faktörlerin Çoklu Göstergeler Çoklu Nedenler Modeliyle İncelenmesi*
}

\section{The Investigation of the Factors Affecting Achievement in Measurement and Evaluation Course with Multiple Indicators Multiple Causes Model}

\author{
Kemal KURŞUN ** Derya ÇOBANOĞLU AKTAN ***
}

\begin{abstract}
Öz
$\mathrm{Bu}$ çalışmanın amacı, öğretmen adaylarının ölçme ve değerlendirme dersindeki başarılarına etki eden faktörlerin çoklu göstergeler çoklu nedenler modeli kullanılarak incelenmesi ve bu faktörlerin başarı üzerindeki etki derecelerinin ortaya çıkarılmasıdır. Çalışmanın verilerini, ölçme ve değerlendirme dersi almış 443 öğretmen adayının, bölümleri, ebeveyn eğitim durumu ve aylık gelirleri, matematik başarı ve kaygı düzeyleri, genel akademik başarı notları, anadolu öğretmen lisesinden mezun olma durumları, eğitimde ölçme ve değerlendirme dersine karşı tutumları, ders çalışmaya ayırdıkları zaman ile ölçme ve değerlendirme ders başarılarıyla ilgili sorulara verdikleri cevaplar oluşturmuştur. Veriler ile ölçme modelinin doğrulanmasından sonra yapısal modelde bağımsız gösterge değişkenler ile gizil değişkenler arasındaki ilişkiler çoklu göstergeler ve çoklu nedenler modeli (ÇGÇN) ile incelenmiştir. Araştırma sonuçlarına göre öğretmen adaylarının eğitimde ölçme ve değerlendirme ders başarılarını, derse karşı tutumları, genel akademik başarıları ve anadolu öğretmen lisesinden mezun olma durumları yordamaktadır. Sosyoekonomik düzeyin, öğretmen adaylarının genel akademik, matematik ve ölçme değerlendirme ders başarılarına manidar bir etkisi yoktur. Duyuşsal özelliklerden matematik kaygısının matematik başarısını negatif yönde, genel akademik başarısını ise pozitif yönde manidar olarak yordadığı sonucuna ulaşılmıştır.
\end{abstract}

Anahtar Kelimeler: yapısal eşitlik modeli, çoklu göstergeler ve çoklu nedenler (ÇGÇN), eğitimde ölçme ve değerlendirme ders başarısı.

\begin{abstract}
The aim of this study is to investigate the factors affecting teacher candidates' measurement and evaluation course achievement with multiple indicators multiple causes modeling and to explore the effects of this factors on the achievement. The data in the study was obtained with a measurement instrument prepared for this purpose. Questions about departments, parent education level and income, mathematics achievement level and anxiety, academic grade, type of graduated high school, attitude toward measurement and evaluation course, achievement of measurement and evaluation course and the time allocated to the study were asked to teacher candidates. After analzing fit indexes of the measurment model, the relations between the independent indicator variables and latent variables were investigated by multiple indicators and multiple causes model. According to the results general academic achievement grade, attitudes toward measurement and evaluation course and type of high graduated school have predicted the achievement level of teacher candidates' in measurement and evaluation course. Socioeconomic level does not have significant impact on general academic achievement grade, mathematics achievement level and achievement of assessment and evaluation course of teacher candidates. It has been concluded that mathematics anxiety variable from affective characteristics significantly has predicted mathematics achievement negatively, and general academic achievement positively.
\end{abstract}

\footnotetext{
* Bu makale, birinci yazar tarafından ikinci yazar danışmanlığında hazırlanan yüksek lisans tez çalışmasından türetilmiştir. ** Kemal KURŞUN, kursun_kemal@hotmail.com

*** Yrd. Doç. Dr. Derya ÇOBANOĞLU AKTAN, Hacettepe Üniversitesi, Eğitim Fakültesi Eğitim Bilimleri Bölümü, Ankara-TÜRKIYE, coderya@gmail.com
}

Ĕgitimde ve Psikolojide Ölçme ve Değerlendirme Dergisi, Cilt 7, Sayı 2, Kıș 2016, 372-387.

Journal of Measurement and Evaluation in Education and Psychology, Vol. 7 Issue 2, Winter 2016, 372-387. 
Keywords: structural equation modeling, multiple indicators and multiple causes (MIMIC), measurement and evaluation course achievement.

\section{GíRiș}

Eğitim ve öğretim faaliyetlerinin başarılı olması için öğretmenlerin belirli alanlarda uzmanlaşma, mesleki bilgi birikimi ve yeterliklere sahip olması gerekmektedir. Bu yeterliliklerden birisi de ölçme ve değerlendirmedir. Ölçme ve değerlendirme eğitimi, öğretmen adaylarına lisans eğitimlerinde ölçme ve değerlendirme dersleri kapsamında verilmekte ve bu becerileri kazanmaları için öğretmen adaylarının dersi başarılı bir biçimde tamamlamaları önem kazanmaktadır.

Yapılan araştırmalar öğrencilerin derslerde başarılı olmasını önemli ölçüde etkileyen bilişsel, duyuşsal, toplumsal ve fizyolojik çok sayıda faktör olduğunu ve bu faktörlere bağlı olarak öğrenci başarısının arttığını ya da azaldığını göstermektedir (Kalender, 2010; Poyraz, 2012; Yenilmez ve Duman, 2008; Yavuz, 2009). Bu kapsamda ölçme ve değerlendirme dersinde başarılı olması gereken öğretmen adaylarının başarı düzeylerini etkileyen faktörlerin tespit edilmesi de önemli bir problem sahası olarak ortaya çıkmaktadır.

Eğitimde ölçme ve değerlendirme alanında yapılan araştırmaların, çoğunlukla öğretmenlerin ölçme ve değerlendirmeye yönelik yeterlilikleri konusunda ve derse karşı tutumla ilgili çalışmalar olduğu belirlenmiştir (Alkharusi, Kazem ve Al Musawai, 201; Erdoğdu, 2010; Süral, 2014; Yaşar, 2014). Öte yandan genel akademik başarıyla ilgili çalışmalar incelendiğinde, öğrencilerin bölümü, cinsiyeti, sosyoekonomik düzeyi, öz-yeterlik, kaygı ve tutumları gibi değişkenlerin genel akademik başarı üzerinde etkisinin olduğu (Poyraz, 2012; Kart, 2012; Süral, 2014) görülmüştür. Matematik başarısında ise, anne-baba eğitim düzeyi, aylık gelir durumu, okul türü ve öğretmen cinsiyeti değişkenleri ile genel akademik başarı, ders kaygısı ve derse karşı tutumun etkili olduğu belirlenmiştir (Erden ve Akgül, 2010; Kalender, 2010; Peker ve Şentürk, 2012; Reçber, 2011; Yenilmez ve Duman, 2008). Ayrıca ders çalışmaya ayrılan zamanın ders başarısını olumlu yönde etkilediği (Özer ve Anıl, 2011; Savaş, Taş ve Duru, 2010) ve yüksek sosyoekonomik düzeyin ögrencilerin fen ve matematik dersi ile genel akademik başarısında etkisinin olduğu görülmüştür (Kalender, 2010; Savaş, Taş ve Duru, 2010; Yavuz, 2009).

Eğitimde ölçme ve değerlendirme özeline bakıldığında öğrencilerin derse yönelik tutumları, bölüm, matematiğe karşı tutum ve matematik dersini alıp almamanın etkilediği (Süral, 2014; Yaşar, 2014), öğrencilerin ölçme ve değerlendirme ders başarılarını baba eğitim durumu ve cinsiyetin yordadığı, tutum ve öz yeterlik algıları gibi duyuşsal özelliklerin manidar olarak yordamadığı görülmüştür (Kart, 2012).

\section{Araştırmanın Amacı}

$\mathrm{Bu}$ çalışmanın amacı, öğretmen adaylarının eğitimde ölçme ve değerlendirme ders başarısı ile bazı demografik ve duyuşsal değişkenler arasındaki ilişkilerin ortaya çıkarılmasıdır. Çalışmada ele alınan değişkenler ve kurulan model yukarıda bahsedilen literatür 1şığında önceki çalışmaların sonuçlarına göre seçilmiş ve kurulmuştur. Yüksek Öğretim Kurumu (YÖK) ders kur tanımına göre güvenirlik, korelasyon, madde ve test istatistikleri ve benzeri konuları öğrenmede matematik bilgisi gerekli olduğu için çalışma kapsamında öğrencilerin matematik başarıları ve matematik kaygıları ele alınmıştır. Ayrıca Anadolu öğretmen lisesi mezunları, lise eğitimlerinde ölçme ve değerlendirme dersi almaktadırlar. Bu yüzden, çalışmada ölçme ve değerlendirme ders başarılarını etkileyen değişkenler arasına Anadolu öğretmen lisesi mezunu olup olmama durumu dahil edilmiştir. İlgili araştırmalar incelendiğinde matematik kaygısı, matematik başarısı ve genel akademik başarının ölçme ve değerlendirme ders başarısı üzerinde, matematik kaygısı ve başarısının ölçme ve değerlendirme dersine karşı tutumla ilişkisi olup olmadığını inceleyen bir çalışma olmadığ 1 görülmüştür. $\mathrm{Bu}$ araştırmada diğer çalışmalardan farklı olarak ölçme ve değerlendirme dersinin matematik alanı ile ilişkisi göz önüne alınarak matematik kaygı ve başarı faktörlerinin, ölçme ve 
değerlendirme ders başarısı ve derse karşı tutum faktörleriyle ilişkisi olup olmadığı ortaya çıkarılmaya çalışılmıştır.

Araştırmada, ölçme ve değerlendirme dersi almış olan öğretmen adaylarının sosyoekonomik düzeyleri, anadolu öğretmen lisesi mezunu olma durumları, eğitimde ölçme ve değerlendirme dersine ayrılan zaman ve derse yönelik tutumları, matematik kaygısı, matematik başarı düzeyi ve genel akademik başarıları ile ölçme ve değerlendirme dersi başarıları arasındaki ilişkilerin incelenerek, bu değişkenlerin öğrencilerin ölçme ve değerlendirme dersi başarısıyla ve birbirleriyle olan ilişki düzeyi belirlenmeye çalışılmıştır. Bu ilişkileri ortaya çıkarmada kullanılan çoklu göstergeler çoklu nedenler modeli ile tahmin edicilerin değişkenleri ne düzeyde açıkladığının yanısıra, tahmin etmede en önemli unsurun hangi değişkenler olduğu da tespit edilmiştir.

Diğer eğitim bilimleri derslerine kıyasla daha fazla sayısal ağırlıklı bir ders olduğu öngörülen ölçme ve değerlendirme dersinin matematik alanı ile ilişkisi göz önüne alındığında matematik kaygı ve başarısının, ölçme ve değerlendirme dersi başarısı ve derse karşı tutum faktörleriyle ilişkisi olup olmadığının araştırılarak öğretmen adaylarının başarısına etki eden faktörlerin belirlenmesinin, onların yeterlilikleri ve eksiklikleri hakkında öngörü sağlanarak başarının arttırılması ve geliştirilmesi hususunda katkısı olacağı düşünülmektedir.

Yapılan alanyazın taramasında eğitimde ölçme ve değerlendirme (EÖD) ders başarısını konu alan Kart'ın (2012) yapmış olduğu çoklu regresyon analizi ile yapılan araştırma dışında yurt içi ve yurt dışı çalışmalarında, özellikle yapısal eşitlik modellemesi geliştirilerek model üzerinde karşılıklı etkilerin ve ilişkilerin analiz edildiği bir çalışmaya rastlanılmamıştır. Bu özelliği ile araştırmanın alana katkı sağlayacağı öngörülmektedir. Çalışmanın yöntemi hakkında detaylara geçmeden önce, aşağıdaki bölümde araştırmada kullanılan çoklu göstergeler ve çoklu nedenler modelinden kısaca bahsedilecektir.

\section{Çoklu Göstergeler ve Çoklu Nedenler Modeli (ÇGÇN) (Multiple Indicators and Multiple Causes Model, MIMIC)}

Yapısal eşitlik modelleri (YEM), aralarında ilişki olan birden fazla bağımlı ve bağımsız değişken arasındaki ilişkiyi matematiksel eşitlik yardımıyla açıklar (Çokluk, Şekercioğlu ve Büyüköztürk, 2014). Regresyon analizlerine benzemekle birlikte, yapılara ölçme hatalarını ve hatalar arasındaki ilişkileri de dahil eder (Yılmaz ve Çelik, 2013). Ayrıca gizil yapılar arası ilişkileri analiz eden yapısal eşitlik modeli bu özelliği ile, karşılaştırılan iki veya daha çok nedensel modelin korelasyon matrisinin uygunluğunu test etmek amacıyla kullanılan, regresyon modellerinin devamı niteliğindeki gözlenen değişkenler arası ilişkileri analiz eden yol analizinden de farklılaşır (Wang ve Wang, 2012).

Çoklu göstergeler ve çoklu nedenler modeli yapısal eşitlik modelinin alt unsuru olarak tanımlanabilir. YEM analizlerinde olduğu gibi ölçme modeli ve yapısal modelden oluşmaktadır. Ölçme modeli gizil değişkenleri gözlenen değişkenlere bağlar, gözlenen değişkenlerin gizil değişken tarafından nasıl tanımlandığını gösterir. Yapısal model ise gizil değişkenler ile bağımsız gösterge değişkenler arasındaki ilişkiyi belirler (Brown, 2015; Baldemir, Özkoç ve İşçi, 2009; Kline, 2015). 


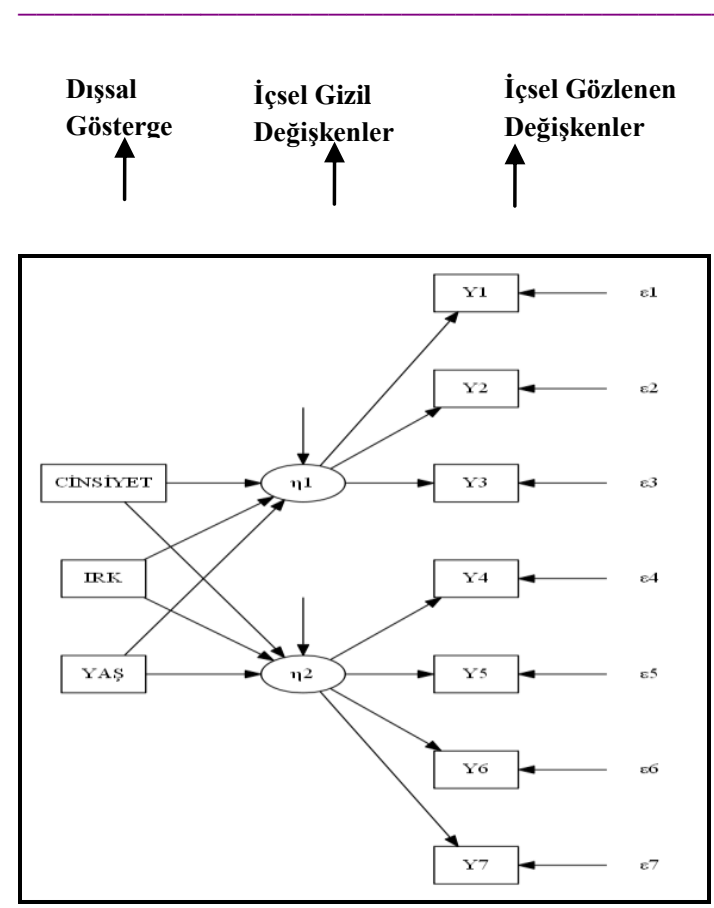

Şekil 1. Çoklu Göstergeler ve Çoklu Nedenler (ÇGÇN) Modeli

Çoklu göstergeler ve çoklu nedenler (mimic) model yaklaşımı birçok neden ve gösterge değişkeni içeren gizil değişkenlerin istatistiksel teorisine dayanmaktadır. Özellikle sosyal araştırmalarda gözlenemeyen değişkenlerin incelenmesinde kullanılan, çok sayıda gösterge değişkenin içsel gizil değişkeni temsil ettiği ve çok sayıda nedensel etkilerin de (tahmin edici gözlenenlerin) içsel gizil değişkenleri etkilediği bir yöntemdir (Brown, 2015; Baldemir, Özkoç ve İşçi, 2009; Kline, 2015). Şekil 1'de çoklu göstergeler ve çoklu nedenler modeline bir örnek sunulmuştur. Kovaryans yap1 analizlerinde çoklu göstergeler ve çoklu nedenler modeli, ölçme modelinin bir gizil değişken yerine, bir ya da bir kaç gizil değişkenden oluştuğu, çok sayıda içsel göstergenin içsel gizil değişkeni ölçmek için kullanıldığı ve çoklu nedensel etkilerin gösterildiği, bütün gizil değiş̧kenlerin bir ölçme modeli altında toplandığı bir yöntemdir. Gizil değişkenler, dışsal gizil değişkenleri mükemmel temsil ettiği varsayılan tahmin edici gösterge değişkenler (cinsiyet, ırk gibi değişkenleri ölçmede ölçme hatası olmadığı kabul edilir) tarafından etkilenir. Dışsal gizil değişkenlerin, bağımsız gösterge değişkenler olarak tanımlandığı bu modellerde gizil değişkenler ile demografik değişkenler arasındaki nedensel ilişkiler araştırılır. Şekil 1'de görülen cinsiyet, 1rk ve yaş değişkenleri demografik değişkenlerdir ve çoklu gösterge çoklu neden (ÇGÇN) modelinde iki gizil değişkeni etkileyen bağımsız gösterge (gözlenen) değişkenlerdir.

\section{YÖNTEM}

\section{Çalışma Grubu}

Araştırmanın çalışma grubunu, 2015-2016 y1lında orta Anadolu'da bölgesindeki bir üniversitede öğrenim gören 443 öğretmen adayı oluşturmaktadır. Çalışmanın uygulanması için gerekli olan etik kurul izni alınmıştır. Araştırmaya katılan 443 öğrenciden sınıf öğretmenliği programındaki öğrenci sayıs1 69 (\%15.6), felsefe bölümünde 85 (\%19.2), ilköğretim matematik bölümünde 35 (\%7.9), fen bilgisi öğretmenliği programında 28 (\%6.3), İngiliz dili bölümünde $53(\% 12)$, bilgisayar ve öğretim teknolojileri programında 84 (\%19), psikolojik danışma ve rehberlik programında 51 (\%11.5), okul öncesi öğretmenliğinde ise $38(\% 8.6)$ dir.

\section{Veri Toplama Araçları}

Araştırmadaki veriler, üç bölümden oluşan ölçme aracı ile elde edilmiştir. Ölçme aracının ilk bölümünü, öğretmen adaylarının eğitimde ölçme ve değerlendirme dersine ait notları, genel 
akademik başarı not ortalamaları, matematik başarı durumları, anadolu öğretmen lisesi mezunu olup olmadıkları, bölümleri, haftalık ders çalışmaya ayırdıkları zaman, ebeveyn öğrenim ve gelir düzeyleri ile ilgili demografik bilgilerini içeren 9 madde oluşturmaktadır. İkinci bölümde Fennema ve Sherman tarafindan 1976 yılında geliştirilen ve Tağ (2000) tarafından Türkçeye uyarlanan Matematik ve test kaygısı olmak üzere 2 alt faktörden oluşan ölçme aracındaki matematik kaygısını ölçen 9 maddelik bölüm kullanılmıştır $(\alpha=0.84)$. Ölçme aracının üçüncü bölümünde Aktaş ve Alıcı (2012) tarafından geliştirilen "Eğitimde Ölçme ve Değerlendirme Dersine Yönelik Tutum Ölçeği" kullanılmıştır. Ölçek, öğretmen adaylarının ölçme değerlendirme dersine yönelik olan tutumlarını bilişsel, duyuşsal ve davranışsal anlamda ölçmek amacıyla 20 maddeden oluşmuştur. Üç faktörden oluşan ölçeğin alt boyutları sırasıyla bilişsel $(\alpha=0,911)$, davranışsal $(\alpha=0,898)$ ve duyuşsal $(\alpha=0,845)$ tutum olarak adlandırılmıştır. Ölçeğin tümüne ait güvenirlik katsayısı $\alpha=0.944$ bulunmuştur.

\section{Verilerin Analizi}

Bu çalışmada verilerin analizi için SPSS 15.0 ve MPLUS 6.0 programları kullanılmıştır. Öncelikle, matematik başarı düzeylerine, genel akademik başarı notları, eğitimde ölçme ve değerlendirme dersi başarı notları ve derse karşı tutumları ile matematik kaygı düzeylerine ilişkin betimsel istatistikler hesaplanmıştır. Verilerin yapılacak analizler için uygun olup olmadığı incelenmek üzere, verilerin doğrulanması ile kayıp değer ve uç değer analizleri yapılmıştır. Ayrıca veriler düzenlenirken hatalı

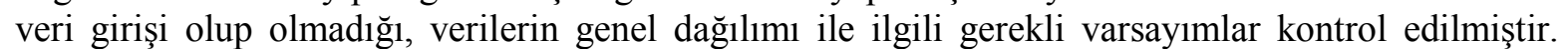
Varsayımların incelenmesi sonucu çoklu normal dağılım varsayımı dışında bir soruna rastlanılmadığı görülmüş ve verilerin analize uygun olduğu sonucuna varılmıştır. Çoklu normallik sağlanamadığ için yapısal eşitlik modeli analizinde standart hatalardan etkilenmeyen en çok olabilirlik tahmin edicisi metodu (maximum likelihood estimation with robust standard errors, MLR) kullanılmıştır (Wang ve Wang, 2012).

Araştırma problemini cevaplamak için, öğrencilerin başarılarını etkileyen faktörlere ilişkin çoklu göstergeler çoklu nedenler modeli analizi için öncelikle ölçme modeli testi gerçekleştirilmiştir. $\mathrm{Bu}$ çalışmada, ölçme modeli için sosyo ekonomik düzey (SED), KAYGI ve TUTUM (TUT1, TUT2, TUT3) gizil değişkenlerine ait gözlenen değişkenler ile aralarındaki standartlaştırılmış ve standartlaştırılmamış katsayılar elde edilmiştir. Araştırmada ölçme başarısı (ÖLÇME), genel akademik başarı (AKADEMIK) ve matematik başarısı (MATEMATIK) değişkenleri, sırasıyla OLCB, GAB ve MATB değişkenleri tarafından temsil edilen tek gözlenen değişkenli gizil değişkenlerdir. Ancak bunlarda ölçme hatası olmadığı düşünülerek işlem yapılması yanlı tahminler elde edilmesine neden olabilir. Bu sebeple modelde güvenirlik katsayıs1, $\mathrm{r}=0,80$ olarak kabul edilmiş ve bu doğrultuda bu gizil değişkenler için hata varyansları da analize dahil edilerek gizil değişkenlere ait faktör yükleri elde edilmiştir.

Oluşturulan ölçme modelinin uyum sonuçları kontrol edilerek MPLUS 6'da yapılan analiz sonuçlarına göre modelin daha iyi uyum göstermesi için bazı modifikasyonlara gidilmiş ve nihai model oluşturulmuştur. Bu kapsamda, T11 "Sınıfta EÖD dersi ile ilgili konuları tartışmaktan hoşlanırım." ile T10 "EÖD dersindeki öğrendiğim bilgileri çevremdeki insanlara anlatmaktan zevk alırım." maddeleri arasında, T20 "EÖD dersinde işlenen konular bana karmaşık gelir." ile T17 "EÖD dersi benim için stres kaynağıdır." maddeleri arasında, T19 "EÖD dersine çalışmak beni mutsuz eder." ile T18 "EÖD dersine girmek benim için zaman kaybıdır." maddeleri arasında ve K9 "Matematik beni huzursuz eder ve kafamı karıştırır." ile K8 "Zor matematik problemleri ile uğraştığımı düşündüğüm zaman kendimi çaresiz hissederim." maddeleri arasında modifikasyona gidilerek model uyum değerleri iyileştirilmiştir. Ayrıca, matematik kaygısı ile ilgili ölçme aracındaki maddelerin faktör yükleri ve içeriğinin incelenmesi sonucu K1 "Matematik beni hiç korkutmaz.", K2 "Matematik beni gerginleştirir." ve K3 "Matematik problemlerini çözebilmek konusunda genelde hiç endişelenmem." maddelerinin birbirine olan benzerliği dikkate alınarak madde birleştirme (item parcel) uygulamas1 ile MPLUS6 programında aritmetik ortalamaları alınmak suretiyle $(\mathrm{K} 1+\mathrm{K} 2+\mathrm{K} 3) / 3=\mathrm{KAY} 1$ değişkeni olarak tek maddede birleştirilmiştir.

Ölçme modellerinin test edilmesinden sonra, oluşturulan yapısal modelde, 
a) TUTUM gizil değişkenine, KAYGI ve SED gizil değişkenlerinin etkisi,

b) MATEMATIKK gizil değişkenine, TUTUM, KAYGI ve SED gizil değişkenlerinin etkisi,

c)AKADEMIK başarı gizil değişkenine, TUTUM, KAYGI, MATEMATIK ve SED gizil değişkenlerinin etkisi,

d) ÖLÇME gizil değişkenine ise, AKADEMIK, TUTUM, KAYGI, MATEMATIK ve SED gizil değişkenlerinin etkisi olup olmadığına dair yapısal ilişkiler incelenmiştir.

e) Ayrıca ZAMAN gösterge değişkeninin TUTUM ve ÖLÇME gizil değişkenlerine etkisi ile AOL gösterge değişkeninin TUTUM, ÖLÇME, MATEMATIK ve AKADEMIK gizil değişkenlerine etkisi olup olmadığı çoklu göstergeler ve çoklu nedenler (ÇGÇN) modeli kapsamına uygun olarak oluşturulan yapısal model altında incelenmiştir.

Araştırmada ölçme modeli ve yapısal modellerin test edilmesi aşamasında güçlendirilmiş (robust) en çok olabilirlik (Maximum Likelihood Robust, MLR) yöntemi kullanılmıştır. MLR, kategorik ve sürekli verilerden oluşan modellerde kullanabilen, kayıp veriler olduğunda analiz yapabilen standart hatalara dayanıklı bir yöntemdir (Wang ve Wang, 2012).

\section{BULGULAR}

Katılımcıların genel akademik başarı notları, eğitimde ölçme ve değerlendirme dersi başarı notları ve derse karşı tutumları ile matematik kaygı düzeylerine ilişkin betimsel istatistikler incelendiğinde aşağıdaki bulgular elde edilmiştir.

Tablo 1. Başarı, Tutum, ve Kaygı Değişkenlerine ait Betimsel İstatistikler

\begin{tabular}{lcccc}
\hline & Min. & Max & Ort. & S.D \\
\hline 2014-2015 Yılı Akademik Başarı Notu & 1.68 & 3.95 & 3.097 & .39401 \\
Ölçme ve Değerlendirme Dersi Başarı Notu & 37 & 98 & 82.19 & 11.797 \\
Bilişsel Tutum & 8.00 & 40.00 & 29.970 & 6.1459 \\
Davranışsal Tutum & 7.00 & 35.00 & 18.760 & 6.0459 \\
Duyuşsal Tutum & 5.00 & 25.00 & 18.186 & 4.5638 \\
TUTUM & 20.00 & 100.00 & 66.917 & 14.385 \\
KAYGI & 9.00 & 45.00 & 21.972 & 8.250 \\
\hline
\end{tabular}

Tablo 1'deki bulgulara göre katılımcıların kaygı faktörü için toplam puanlarının 9 ile 45 arasında değişmekte olduğu ve 45 puan üzerinden 21.97 puan ortalaması ile matematik kaygı düzeylerinin düşük seviyelerde olduğu görülmektedir. Eğitimde ölçme ve değerlendirme dersine karşı tutumla ilgili bilişsel tutum alt boyutunun 40 puan üzerinden 29.98 ortalama puanı ve duyuşsal tutumun 25 puan üzerinden 18.18 'lik puan ortalamasıyla yüksek, davranışsal tutumun 35 puan üzerinden 18.76 puan ortalamasıyla nispeten daha düşük olduğu görülmektedir. Tutum faktörüne ait toplam tutum puanları 20 ile 100 arasında değişmekte ve 100 puan üzerinden 66.91'lik puan ortalaması ile öğretmen adaylarının eğitimde ölçme ve değerlendirme dersine yönelik tutumlarının olumlu düzeyde olduğu ifade edilebilir. Genel akademik başarı notları en düşük 1.68 ile en yüksek 3.95 puanlar arasında değişmektedir. Araştırmaya katılan öğretmen adaylarına ait genel akademik başarı not ortalamalarının 4 üzerinden 3.07 olduğu görülmektedir. Bu nedenle öğretmen adaylarının akademik başarılarının iyi seviyede olduğu ifade edilebilir. Eğitimde ölçme ve değerlendirme dersi başarı notları, en düşük 37 ile en yüksek 98 puanları arasında değişmekte ve ortalamanın 100 üzerinden 82,19 olduğu ve bu nedenle genel olarak ölçme ve değerlendirme dersinde başarılı oldukları ifade edilebilir. 
Kurşun, K., Çobanoğlu Aktan, D. / Eğitimde Ölçme ve Değerlendirme Dersinde Başarıyı Etkileyen Faktörlerin Çoklu Göstergeler Çoklu Nedenler Modeliyle İncelenmesi

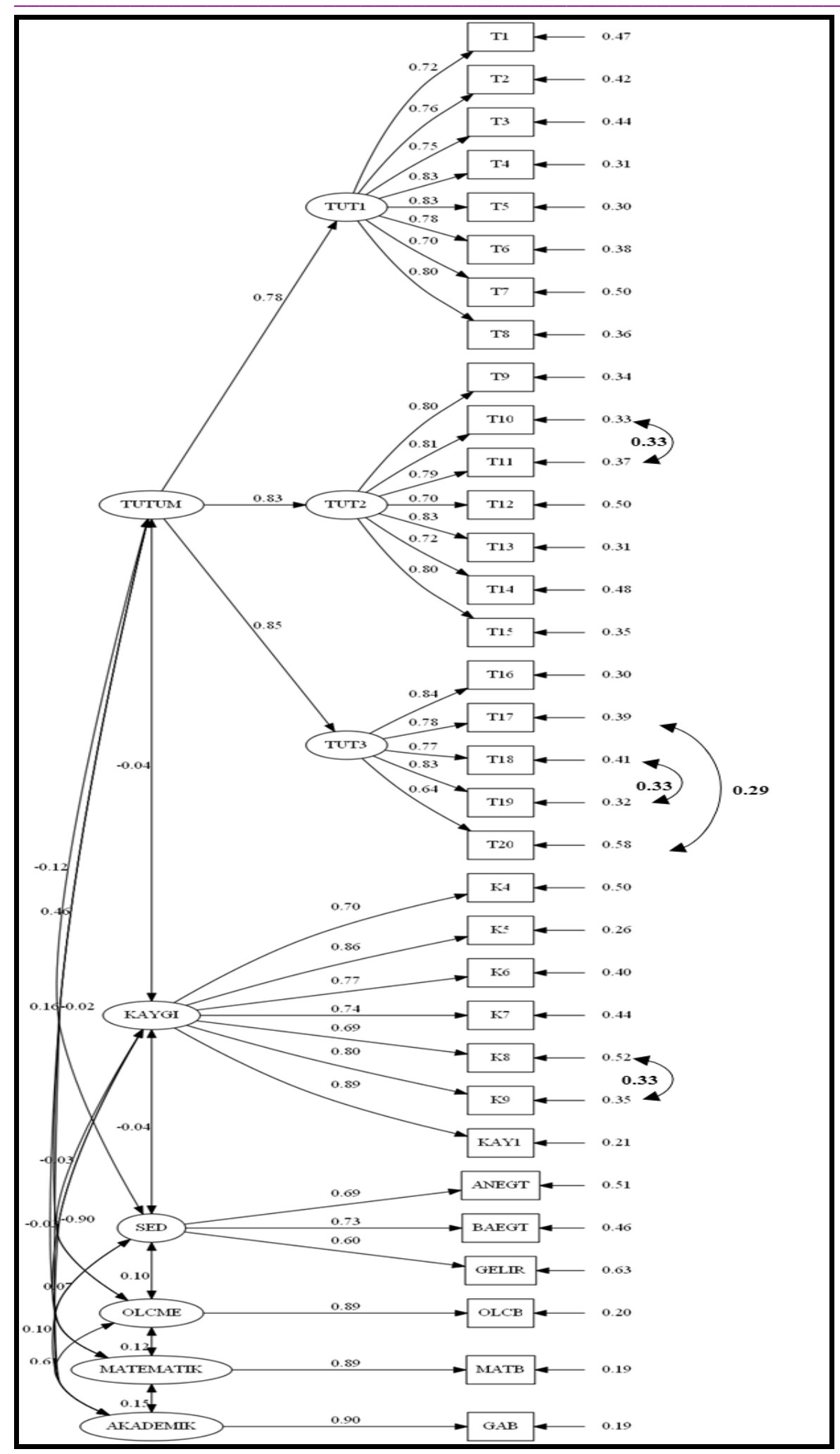

Şekil 2. Ölçme Modeli

\section{Ölçme ve yapısal modele ilişkin bulgular}

Şekil 2'de görülen ölçme modeline ilişkin uyum iyiliği indeksleri değerleri Tablo 2'de sunulmaktadır. Bu değerler incelendiğinde ki-kare değerinin anlamlı çıktığı görülmektedir. 
Tablo 2. Ölçme Modeli Uyum İndeksi Sonuçları

\begin{tabular}{lcccccc}
\hline & $\chi^{2}$ & $\chi^{2} /$ s.d. & RMSEA & NNFI/TLI & CFI & SRMR \\
\hline Ölçme Modeli & 957.352 & $957.352 / 476$ & 0.048 & 0.934 & 0.940 & 0.052 \\
& $(\mathrm{p}=0,00)$ & $=2.01$ & & & & \\
\hline
\end{tabular}

Ki-kare değerinin genelde anlamlı çıktığını görürüz, çünkü bu değer örneklem büyüklüğüne oldukça duyarlıdır (Şimşek, 2007). Ki kare ve serbestlik derecesi oranının ( $\chi^{2} /$ s.d.) 2,01 olması ve RMSEA değerinin 0,048 olması iyi uyumu göstermektedir. NNFI değerinin 0,934 olmas1 ve CFI değerinin 0,940 olmas1 kabul edilebilir uyumu, SRMR değerinin 0,052 olmas1 da modelin iyi uyum gösterdiğini belirtmektedir. Bu sonuçlara göre ölçme modelinin doğrulandığı söylenebilir. Ölçme modeline ait değişkenlerin faktör yükleri ve hata varyanslarına ilişkin değerlerin gösterimi Şekil 2'de, analize ilişkin standartlaştırılmış yükler, $\mathrm{p}$ değerleri, açıklanan varyans ve hata varyansları ise Tablo 3'de verilmiştir.

Tablo 3. Ölçme Modeline Ait Analiz Sonuçları

\begin{tabular}{|c|c|c|c|c|c|}
\hline Gizil Değişken & $\begin{array}{l}\text { Gözlenen } \\
\text { Değişken }\end{array}$ & $\begin{array}{c}\text { Standartlaş- } \\
\text { tırılmış Yükler }\end{array}$ & $P$-değeri & $\begin{array}{c}\text { Toplam } \\
\text { Varyans }\end{array}$ & $\begin{array}{c}\text { Hata } \\
\text { Varyanslart }\end{array}$ \\
\hline BİLİŞSEL & $\mathrm{T} 1$ & 0.724 & 0.00 & 0.525 & 0.475 \\
\hline ÖZELLİKLER & $\mathrm{T} 2$ & 0.757 & 0.00 & 0.573 & 0.427 \\
\hline \multirow[t]{6}{*}{ (TUT1) } & $\mathrm{T} 3$ & 0.748 & 0.00 & 0.559 & 0.441 \\
\hline & $\mathrm{T} 4$ & 0.829 & 0.00 & 0.687 & 0.313 \\
\hline & T5 & 0.832 & 0.00 & 0.692 & 0.308 \\
\hline & T6 & 0.784 & 0.00 & 0.614 & 0.386 \\
\hline & $\mathrm{T} 7$ & 0.704 & 0.00 & 0.496 & 0.504 \\
\hline & $\mathrm{T} 8$ & 0.797 & 0.00 & 0.635 & 0.365 \\
\hline DAVRANISSAL & T9 & 0.808 & 0.00 & 0.654 & 0.346 \\
\hline ÖZELLIKKLER & $\mathrm{T} 10$ & 0.814 & 0.00 & 0.662 & 0.338 \\
\hline \multirow[t]{5}{*}{ (TUT2) } & $\mathrm{T} 11$ & 0.793 & 0.00 & 0.628 & 0.372 \\
\hline & $\mathrm{T} 12$ & 0.702 & 0.00 & 0.492 & 0.508 \\
\hline & $\mathrm{T} 13$ & 0.830 & 0.00 & 0.689 & 0.311 \\
\hline & T14 & 0.720 & 0.00 & 0.519 & 0.481 \\
\hline & $\mathrm{T} 15$ & 0.804 & 0.00 & 0.646 & 0.354 \\
\hline DUYUŞSAL & T16 & 0.837 & 0.00 & 0.701 & 0.299 \\
\hline ÖZELLİKLER & $\mathrm{T} 17$ & 0.777 & 0.00 & 0.604 & 0.396 \\
\hline \multirow[t]{3}{*}{ (TUT3) } & $\mathrm{T} 18$ & 0.767 & 0.00 & 0.588 & 0.412 \\
\hline & T19 & 0.826 & 0.00 & 0.682 & 0.318 \\
\hline & $\mathrm{T} 20$ & 0.643 & 0.00 & 0.413 & 0.587 \\
\hline \multirow[t]{3}{*}{ TUTUM } & TUT1 & 0.777 & 0.00 & 0.604 & 0.396 \\
\hline & TUT2 & 0.832 & 0.00 & 0.693 & 0.307 \\
\hline & TUT3 & 0.851 & 0.00 & 0.724 & 0.276 \\
\hline \multirow[t]{7}{*}{ KAYGI } & K4 & 0.704 & 0.00 & 0.496 & 0.504 \\
\hline & K5 & 0.858 & 0.00 & 0.737 & 0.263 \\
\hline & K6 & 0.771 & 0.00 & 0.595 & 0.405 \\
\hline & K7 & 0.747 & 0.00 & 0.558 & 0.442 \\
\hline & K8 & 0.692 & 0.00 & 0.479 & 0.521 \\
\hline & K9 & 0.804 & 0.00 & 0.646 & 0.354 \\
\hline & KAY1 & 0.889 & 0.00 & 0.791 & 0.209 \\
\hline \multirow{3}{*}{ SED } & ANEGT & 0.697 & 0.00 & 0.486 & 0.516 \\
\hline & BAEGT & 0.731 & 0.00 & 0.534 & 0.466 \\
\hline & GELIR & 0.603 & 0.00 & 0.364 & 0.636 \\
\hline ÖLÇME & OLCB & 0.894 & 0.00 & 0.80 & 0.20 \\
\hline AKADEMIK & GAB & 0.898 & 0.00 & 0.806 & 0.194 \\
\hline MATEMATİK & MATB & 0.897 & 0.00 & 0.804 & 0.196 \\
\hline
\end{tabular}

Şekil 2'de görülen ölçme modelinde TUTUM'a ait TUT1 gizil değişkeni olan bilişsel tutumun ilk göstergesi ele alındığında T1 "EÖD dersi önem verdiğim bir derstir." değişkeni korelasyon katsayısı 0.72'dir. $\mathrm{Bu}$ değer, TUT1 gizil değişkenine ait T1 gözlenen değişkeninin faktör yükünü göstermektedir. Kline'a (2005) göre, faktör yük değeri, maddelerin faktörlerle olan ilişkisini açılar. Bilişsel tutum boyutu en çok 0.83 yük katsayısı ile T5 "EÖD dersini almanın, öğrenci başarısını 
belirlemede yapılacak çalışmaların önemini kavramak için gerekli olduğuna inanırım." gözlenen değişkeni tarafından açıklanmaktadır. TUT2 gizil değişkeni olan davranışsal tutum boyutunda en yüksek faktör yüküne sahip değişkenin ise 0.83 ile T13 "Arkadaşlarımla EÖD konularını konuşmayı severim." olduğu saptanmıştır. Aynı şekilde, duyuşsal tutum boyutu (TUT3) ise en çok T16 "EÖD dersine çalışmak bana sıkıcı gelir." tarafından açıklanmaktadır. İkinci düzeyde ise TUTUM gizil değişkeninin en çok 0.85 ile duyuşsal tutum boyutu olan TUT3 tarafından açıklandığı görülmüştür.

Tablo 3'ten de görüldüğü gibi KAYGI gizil değişkeninin 0.889 ile KAY1 değişkeni tarafından açıklandığ1 görülmüştür. KAY1 değişkeni K1 "Matematik beni hiç korkutmaz.", K2 "Matematik beni gerginleştirir." ve K3 "Matematik problemlerini çözebilmek konusunda genelde hiç endişelenmem." değişkenlerinin içerik benzerlikleri olduğunun değerlendirilmesi sonucu madde birleştirme (item parcel) uygulaması ile oluşturulmuştur. SED değişkeninin en çok 0.73 faktör yük katsayısı ile baba eğitim değişkeni (BAEGT) tarafından açıklandığı görülmektedir.

Yapısal modele ilişkin uyum indeksleri değerlendirildiğinde ki-kare değerinin anlamlı çıktığ görülmektedir. Anlamlı çıkmasının sorun teşkil etmesi nedeniyle bakılan diğer bir ölçüt olan ki kare ve serbestlik derecesi oranının $\left(\chi^{2} /\right.$ s.d.) 1,95 olması iyi uyumu göstermektedir. RMSEA değerinin 0.046 , NNFI değerinin 0.931 ve SRMR değerinin 0.05 olmas1 da iyi uyumu göstermektedir. CFI değerinin 0.938 olması kabul edilebilir uyumu belirtmektedir.

Tablo 4. Yapısal Model Uyum İndeksi Sonuçları

\begin{tabular}{lcccccc}
\hline & $\chi^{2}$ & $\chi^{2} /$ s.d. & RMSEA & NNFI/TLI & CFI & SRMR \\
\hline Yapisal Model & $\begin{array}{c}1045.977 \\
(\mathrm{p}=0,00)\end{array}$ & $\begin{array}{c}1045.977 / 536 \\
=1,95\end{array}$ & 0.046 & 0.931 & 0.938 & 0.05 \\
& & & & & \\
\hline
\end{tabular}

Yapısal model analizi sonucunda arasında ilişki olup olmadığı görülmek istenen gizil değişkenler aras1 etkiler ile çoklu göstergeler ve çoklu nedenler modeli olarak tanımlanan gösterge değişkenler (AOL, ZAMAN) ile gizil değişkenler arasındaki etkilerden anlamlı $(\mathrm{p}<0,05)$ olanlar Şekil 3'te verilmiştir. Bu bulgulara göre ölçme modelinin doğrulandığı ve yapısal modelin iyi uyum sağladığı görülmektedir.

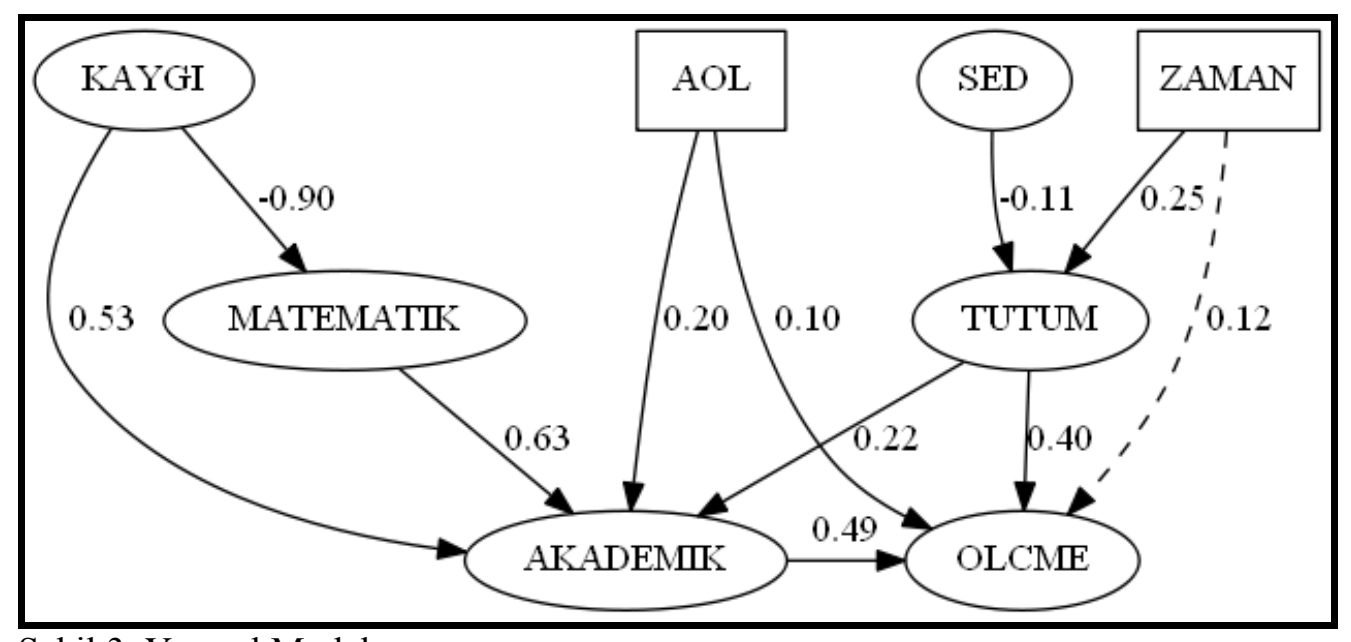

Şekil 3. Yapısal Model

Yapısal modele ilişkin gizil değişkenlere ait açıklanan varyanslar $\left(\mathrm{R}^{2}\right)$ Tablo 5'te verilmiş olup gizil değişkenlere ait açıklanan varyans yüzdelerinin hepsinin anlamlı $(\mathrm{p}<0.05)$ olduğu görülmektedir. Tek faktörlü ölçeklerde açıklanan varyansın $\% 30$ ve daha fazla olması yeterli görülebilir. Çok faktörlü ölçeklerde ise açıklanan varyansın daha yüksek olması beklenir. Sosyal bilimlerde açıklanan varyansın \%40 ile \%60 arasında olması yeterli olarak kabul edilir (Çokluk vd., 2014). Elde edilen bu bulguların ardından gizil değişkenler arasındaki ve gösterge değişkenler ile gizil değişkenler arasındaki yapısal ilişkileri daha detaylı olarak aşağıda incelenmiştir. 
Tablo 5. Yapısal Model Gizil Değişkenlere Ait Açıklanan Varyanslar

\begin{tabular}{|c|c|c|c|c|}
\hline Gizil Değişken & Tahmin & Std. Hata & $\begin{array}{l}\text { Tahmin/ } \\
\text { Std.Hata }\end{array}$ & P Değeri \\
\hline TUT1 Bilişsel Tutum & 0.598 & 0.052 & 11.49 & 0.00 \\
\hline TUT2 Davranışsal Tutum & 0.641 & 0.056 & 11.55 & 0.00 \\
\hline TUT3 Duyuşsal Tutum & 0.780 & 0.061 & 12.85 & 0.00 \\
\hline TUTUM & 0.079 & 0.028 & 2.86 & 0.004 \\
\hline ÖLÇME BAŞARI & 0.534 & 0.066 & 8.08 & 0.00 \\
\hline AKADEMİK BAŞARI & 0.161 & 0.051 & 3.15 & 0.002 \\
\hline MATEMATİK BAŞARI & 0.821 & 0.044 & 18.60 & 0.00 \\
\hline
\end{tabular}

Analiz sonuçlarına göre yapısal modelin tutumla ilgili kısmında, eğitimde ölçme ve değerlendirme dersine karşı tutum ile matematik kaygısı arasında -0.051 'lik $(\mathrm{p} ; 0.381>0,05)$ ve anadolu öğretmen lisesi mezunu olmaları arasında $-0,048$ 'lik istatistiksel olarak anlamlı olmayan $(p=0,351)$ bir ilişki olduğu görülmektedir. Öte yandan tutum ile sosyoekonomik düzey arasında -0.113 'lük ve derse ayrılan zaman arasında $0.246^{\prime}$ 'lı istatistiksel olarak anlamlı bir ilişki bulunmuştur. Bu değer derse zaman ayıranların tutum puanlarının derse zaman ayırmayanlara oranla daha yüksek olduğunu göstermektedir.

TUTUM $=\mathbf{0 . 2 4 6} *$ ZAMAN - 0.113*SED $-0.051 *$ KAYGI - 0.048*AOL

Bu sonuçlara göre sosyo ekeonomik düzey, kaygı, Anadolu öğretmen lisesi mezunu olma durumu ve zaman değişkenlerinin tutumun yüzde sekizini açıkladığı, açıklanan varyansın çok düşük olduğu, eğitimde ölçme ve değerlendirme dersine karşı tutum gizil değişkenine en çok açıklayan değişkenin 0.246 'lık etkiyle derse ayrılan zaman olduğu görülmektedir.

Modelin matematik başarısı ile ilgili kısmının sonuçları incelendiğinde, matematik başarısının sosyoekonomik düzey ile arasında 0.034 'lük $(\mathrm{p}=0.391>0,05)$; EÖD dersine karşı tutum ile arasında 0.047'lük ( $\mathrm{p}=0,189)$; anadolu öğretmen lisesi mezunu olmaları ile arasında 0,033 'lük $(\mathrm{p}=0,294)$ düzeyde istatistiksel olarak anlamlı olmayan bir ilişki olduğu görülmektedir. Matematik kaygısı ile matematik başarısı arasında -0.904 'lük negatif ve istatistiksel olarak anlamlı $(\mathrm{p}=0,00)$ bir ilişki bulunmuştur. Bu değer kaygıdaki artışın başarıda azalışa veya azalışın başarıda artışla sonuçlandığını göstermektedir.

\section{Matematik Başarısı $=0.034 * \mathrm{SED}-\mathbf{0 . 9 0 4} * \mathrm{KAYGI}+0.033 * \mathrm{AOL}-0.047 * \mathrm{TUTUM}$}

Açıklanan varyansa bakıldığında, sosyoekonomik düzey (SED), matematik kaygısı (KAYGI), Anadolu öğretmen lisesi mezunu olup olmama (AOL) ve eğitimde ölçme ve değerlendirme dersine karşı tutum (TUTUM) değişkenlerinin, matematik başarısının \%82'sini açıkladığı görülmektedir. Matematik başarısına anlamlı etkiyi kaygı değişkeninin yaptı̆̆g görülmüştür.

Yapısal modelin genel akademik başarı gizil değişkenine ilişkin analiz sonuçlarına göre genel akademik başarının sosyoekonomik düzey ile arasında 0.086 'lük pozitif yönde, zayıf ve istatistiksel olarak anlamlı olmayan (p; $0.159>0,05)$ bir ilişki mevcuttur. Matematik kaygısı ile akademik başarı arasında 0.533 'lük $(\mathrm{p}=0,005)$ tutum ile arasında $0.218^{\prime}$ lük $(\mathrm{p}=0,001)$ matematik başarısı ile arasında 0,629 'luk düzeyde ve katılımcıların anadolu öğretmen lisesi mezunu olmaları ile arasında 0,204'lük $(\mathrm{p}=0,00)$ istatistiksel olarak anlamlı bir ilişki olduğu görülmektedir.

\section{Genel Akademik Başarı $=0.086 * \mathrm{SED}+\mathbf{0 . 5 3 3} *$ KAYGI $+0.204 * \mathrm{AOL}+\mathbf{0 . 2 1 8} *$ TUTUM + 0.629*MATEMATIK}

$\mathrm{Bu}$ sonuçlara göre sed, kaygı, aol, tutum ve matematik değişkenlerinin genel akademik başarının \%16.1'ini açıkladığı görülmektedir.

Yapısal modelde eğitimde ölçme ve değerledirme ders başarısı gizil değişkeni ile ilgili ilişkiler incelendiğinde, sosyoekonomik düzey ile arasında 0.083 'lük zayıf ve istatistiksel olarak anlamlı 
olmayan ( $\mathrm{p} ; 0.136>0,05)$, matematik kaygısı ile arasında 0.222 'lik düzeyde pozitif ancak anlamlı olmayan $(\mathrm{p}=0,182)$, matematik başarısı ile arasında ise, 0,247'lik düzeyde ve anlamlı olmayan $(p=0,149)$ bir ilişki bulunmuştur. Ölçme ve değerlendirme dersine karşı tutum ile ders başarısı arasında 0.404'lük düzeyde ve istatistiksel olarak anlamlı $(\mathrm{p}=0,00)$ bir ilişki bulunmuştur. Genel akademik başarı notu ile ölçme ders başarı notu arasında da 0,489'luk düzeyde yüksek, pozitif yönde ve anlamlı $(\mathrm{p}=0,00)$ bir ilişki bulunmuştur. Katılımcıların Anadolu öğretmen lisesi mezunu olmaları ile ölçme başarısı arasında $0,101^{\prime}$ lik pozitif yönde ve anlamlı $(\mathrm{p}=0,007)$ bir ilişki olduğu görülmektedir. Anadolu öğretmen lisesi mezunu olanların diğer liselere göre ölçme dersinde düşük düzeyde olsa da daha başarılı oldukları sonucuna ulaşılmıştır. Ölçme ve değerlendirme dersine ayrılan zamanın ölçme ve değerlendirme ders başarısına doğrudan anlamlı etkisi olmadığı, ancak aşağıdaki tabloda görüldüğü üzere pozitif yönde ve anlamlı $0,119^{\prime}$ luk dolaylı etkisi olduğu görülmektedir.

Tablo 6. Ölçme ve Değerlendirme Dersine Ayrılan Zaman ile Ders Başarısı Arasındaki Dolaylı İlişkiler

\begin{tabular}{lcc}
\hline \multicolumn{1}{c}{ Yapısal ilişkiler } & Std. Yükler & P-dĕgeri \\
\hline ZAMAN Tutum dolaylı ÖLÇME & 0.099 & 0.00 \\
ZAMAN Tutum Akademik dolaylı ÖLÇME & 0.026 & 0.007 \\
ZAMAN Tutum Matematik dolaylı ÖLÇME & -0.003 & 0.353 \\
ZAMAN Tutum Matematik Akademik dolaylı ÖLÇME & -0.004 & 0.223 \\
TOPLAM ZAMAN dolaylı ÖLÇME & 0.119 & 0.00 \\
\hline
\end{tabular}

\section{Ölçme Başarısı $=0.083 *$ SED $+0.222 *$ KAYGI $+0.119 *$ ZAMAN $+\mathbf{0 . 1 0 1} *$ AOL $+\mathbf{0 . 4 0 4} *$ TUTUM + 0.489*AKADEMIK + 0.247*MATEMATIK}

$\mathrm{Bu}$ sonuçlara göre sosyoekonomik düzey, matematik kaygısı, ölçme ve değerlendirme dersine ayrılan zaman, anadolu öğretmen lisesi mezunu olma, ölçme ve değerlendirme dersine karşı tutum, genel akademik başarı ve matematik başarısı değişkenlerinin ölçme ve değerlendirme ders başarısının \%53.4'ünü açıkladığı görülmektedir. Ölçme ve değerlendirme ders başarısını en çok açıklayan değişkenin 0.489 'luk etkiyle genel akademik başarı olduğu görülmektedir.

$\mathrm{Bu}$ çalışmada öğretmen adaylarının eğitimde ölçme ve değerlendirme ders başarısı ile bazı demografik ve duyuşsal değişkenler arasındaki ilişkiler çoklu göstergeler çoklu nedenler modeli ile incelenmiştir. Analiz sonuçlarına göre aşağıdaki sonuçlara ulaşılmıştır.

Eğitimde ölçme ve değerlendirme dersine karşı tutumu yordayan değişkenleri belirlemek için kurulan model iki aşamalı olarak test edilmiş ve elde edilen bulgular sonucunda modelin verilerle iyi uyum gösterdiği bulunmuştur. Ölçme modeline alınan değişkenlerden, tutumu belirleyen en yüksek faktör yüküne sahip yapının duyuşsal özellikler olduğu görülmüştür. Bu çalışmanın bulgularına göre öğretmen adaylarının eğitimde ölçme ve değerlendirmeye yönelik tutumlarının olumlu düzeyde olduğu söylenebilir. Bu sonuç, Erdoğdu'nun (2010) genel anlamda öğretmenlerin ölçme ve değerlendirmeye yönelik tutumlarının olumlu yönde olduğu bulgusuyla desteklenirken, Yaşar'ın (2014), öğretmen adaylarının eğitimde ölçme ve değerlendirme dersine yönelik tutum düzeyleri ile tutumlarının bazı değişkenler açısından incelenmesi amacıyla yaptığı çalışmadaki öğretmen adaylarının eğitimde ölçme ve değerlendirmeye yönelik tutumlarının çok düşük düzeyde olduğu bulgusuyla desteklenmemektedir. Yapısal model incelendiğinde ise, tutumu açıklayan en yüksek faktörün ölçme ve değerlendirme dersi için çalışmaya ayrılan zaman olduğu görülmüştür. Kesiktaş'ın (2006) da belirttiği gibi verimli ders çalışma alışkanlıkları edinmiş öğrenciler, okula ve derse karş1 olumlu tutum göstermektedir. Sosyoekonomik düzeyin ise negatif yönde derse karş1 tutuma etki ettiği görülmüştür. Sosyoekonomik düzey gizil değişkenine ait en yüksek faktör yüküne sahip olan değişkenin baba eğitim durumu olduğu sonucuna ulaşılmıştır. Ele alınan matematik kaygısı ve anadolu öğretmen lisesi mezunu olup olmama durumunun ölçme değerlendirme dersine karşı tutuma etkisinin negatif yönde ve manidar olmadığı sonucuna ulaşılmıştır. 
Yapısal modelde matematik başarısını yordayan değişkenler incelendiğinde, başarıyı açılayan faktörün matematik kaygı değişkeni olduğu, matematik kaygısı artıkça başarının düştüğü, azaldıkça başarının arttığı sonucuna ulaşılmıştır. Bu sonuç Erden ve Akgül'ün (2010) yapılan regresyon analizi sonucundaki matematik kaygısının matematik başarısının anlamlı yordayıcısı olduğu ve Peker ve Şentürk'ün (2012) matematik kaygıları ile matematik notları arasında negatif yönlü ve orta düzeyde anlamlı bir ilişkinin olduğu bulgusuyla desteklenmektedir. Sayısal ağırlıklı bir ders olması nedeniyle tutum puanı ile matematik başarısı arasında bir ilişki beklense de anlamlı bir ilişki olmadığ eğitimde ölçme ve değerlendirme dersine karşı tutumun matematik başarısı üzerinde herhangi bir etkisi olmadığı görülmüştür. Bu sonuç, Süral'in (2014) sayısal içerikli bölümlerde öğrenim gören öğrencilerin ölçme ve değerlendirme dersine yönelik daha yüksek bir tutum gösterdikleri ve öğrenim hayatında aldığı matematik dersi, matematik dersine karşı edindiği tutum, lisans eğitimindeki ölçme değerlendirme dersine olan bakış açısına yön verdiği bulgularıyla desteklenmemektedir. Ayrıca sosyoekonomik düzey ve anadolu öğretmen lisesi mezunu olma durumu ile matematik başarısı arasında istatistiksel olarak anlamlı olmayan bir ilişki bulunmuştur. Bu sonuç Yavuz'un (2009) anne ve baba eğitiminin doğrudan ayrıca baba eğitiminin aylık gelir artışı ve öğrencinin dershaneye gitme süresi aracılığı ile öğrencinin matematik-fen puanını pozitif olarak etkilediği ve Kalender'in (2010) sosyoekonomik durumun matematik başarısı üzerinde güçlü bir etkiye sahip olduğu bulgusuyla ve öğrencilerin matematik başarıları ile devam ettikleri okul türleri arasında anlamlı ilişki olduğu sonucuyla desteklenmemektedir.

Yapısal modelde genel akademik başarıyı yordayan değişkenler incelendiğinde, akademik başarıyı açıklayan en yüksek faktörün matematik başarısı olduğu, yine matematik kaygısı değişkeninin de genel akademik başarıyı pozitif yönde etkilediği görülmüştür. Yani matematik kaygısı yüksek düzeyde olan öğretmen adaylarının genel akademik başarısı da yüksektir. Bu durum oldukça ilginçtir. Matematik kaygısı düşük olan öğretmen adaylarının matematik başarı notları yüksek olmasına rağmen genel akademik başarılarının da matematik başarısıyla benzer eğilim göstermesi beklense de tam tersi bir durum ortaya çıkmıştır. Bu sonuçlar, Peker ve Şentürk'ün (2012) genel notları ile matematik kaygıları arasında negatif yönlü ve orta düzeyde anlamlı bir ilişkinin olduğu bulgusuyla desteklenmemekte, matematik notları ile genel notları arasında pozitif yönlü ve yüksek düzeyde anlamlı ilişki olması bulgusuyla desteklenmektedir. Öğretmen adaylarının anadolu öğretmen lisesi mezunu olmasının, diğer okullardan mezun olan öğretmen adaylarına göre genel akademik başarıyı pozitif yönde etkilediği sonucuna varılmıştır. Genel akademik başarıyı etkileyen diğer faktör ise eğitimde ölçme ve değerlendirme dersine karşı tutumdur. Tutum puanı yüksek öğretmen adaylarının genel akademik başarısı notlarının yüksek, tutum puanı düşük olanların akademik başarı notları da düşüktür. Bu sonuç, Süral'in (2014) genel başarı not ortalamaları yüksek olan öğrencilerin derse karşı gösterdiği önem ve bilişsel yeterlik boyutlarında daha yüksek bir tutum sergiledikleri, düşük öğrencilerin ise olumsuz yaklaşım alt boyutunda daha yüksek bir ortalamaya sahip oldukları bulgusuyla desteklenmektedir. Ele alınan demografik değişkenlerden sosyoekonomik düzeyin genel akademik başarıya, manidar bir etkisi olmadığı sonucuna ulaşılmıştır. Taningco (2006), ekonomik durum ile anne ve babanın eğitim seviyesinin öğrencilerin akademik başarının artmasında önemli bir etken olduğunu belirtse de bu durum araştırma sonuçları ile desteklenmemektedir.

Yapısal modelin eğitimde ölçme ve değerlendirme ders başarısını yordayan değişkenleri incelendiğinde, ölçme ve değerlendirme ders başarısını açıklayan en yüksek faktörün genel akademik başarı değişkeni olduğu sonucuna ulaşımıştır. Genel akademik başarısı yüksek düzeyde olan öğretmen adaylarının eğitimde ölçme ve değerlendirme ders başarısı da yüksektir. Ölçme ve değerlendirme ders başarısını etkileyen diğer faktör ise eğitimde ölçme ve değerlendirme dersine karşı tutumdur. Bu sonuç, Kart'ın (2012) öğretmen adaylarının ölçme ve değerlendirme dersi başarılarını duyuşsal özelliklerin manidar olarak yordamadığı bulgusuyla örtüşmemektedir. Öğretmen adaylarının anadolu öğretmen lisesi mezunu olmasının da, diğer okullardan mezun olan öğretmen adaylarına göre ölçme ve değerlendirme ders başarısını pozitif yönde etkilediği sonucuna varılmıştır. Ele alınan demografik değişkenlerden sosyoekonomik düzeyin ölçme ve değerlendirme ders başarısına manidar bir etkisi olmadığı sonucuna ulaşılmıştır. Sayısal ağırlıklı bir ders olarak 
değerlendirilen eğitimde ölçme ve değerlendirme dersinin matematik başarısı ve matematik kaygı faktörleri ile ilişkisi olması beklense de bu faktörlerin ölçme ve değerlendirme ders başarısına manidar bir etkisi olmadığı sonucuna varılmıştır. Eğitimde öçme ve değerlendirme dersine ayrılan zamanın ölçme ve değerlendirme ders başarısına istatistiksel olarak anlamlı doğrudan bir etkisi olmadığı görülse de pozitif yönde dolaylı etkisi olduğu sonucuna ulaşılmıştır. Bu sonuç Özer ve Anıl (2011) ile Savaş, Taş ve Duru'nun (2010) ders çalışma süresiyle ders (fen ve matematik) başarısı arasındaki ilişkinin de anlamlı olduğu sonucu bulgusuyla desteklenmektedir.

$\mathrm{Bu}$ sonuçlara göre araştırmacı ve eğitimcilere öneriler şunlardır. Öğretmen adaylarının eğitimde ölçme ve değerlendirme dersine yönelik tutum düzeylerinin orta seviyelerde olmasının nedenleri tespit edilerek özellikle davranışsal ve duyuşsal boyutta düşük veya olumsuz olan tutumlarının olumlu yönde artmasını sağlayacak çözümler (derse hazır gelmeleri için ödev, sunum, proje uygulama görevi vb.) araştırılmalıdır.

Öğrencinin derslerine çalışmak için ayırdığı zaman değişkeninin başarıya ve derse karşı tutumlarına etkisi olduğu görülmektedir. Derse hazırlanma kapsamında yapılan çalışmalarda, derste hazır olma düzeyinin arttırılarak ders içi başarıyı olumlu etkileyen ve derse karşı olumlu tutum gösterilmesini sağlayan farkındalık eğitimleri verilebilir. Bu kapsamda, öğrencilere, ders çalışmaya zaman ayırarak derse hazırlıklı gelmelerinin derse karşı tutumlarına ve başarılarına olumlu etkisinin olacağı da vurgulanmalidir.

Duyuşsal özelliklerden biri olan matematik kaygısının yapılan araştırmada matematik başarısına en büyük etki eden faktör olduğu sonucundan hareketle, öğrencilere matematiği sevdirmeye yönelik gerekli etkinlikler ve matematiğe karşı özgüven düzeylerini arttırmak için gerekli çalışmaları planlayıp, uygulamaları konusunda gerekli adımlar atılabilir.

$\mathrm{Bu}$ araştırma, orta Anadolu bölgesindeki bir üniversitede ölçme ve değerlendirme dersi almış öğrenciler üzerinde yapılmıştır. Farklı üniversite ya da üniversiteler arası karşılaştırma amaçlı ya da benzer nitelikte heterojen gruplarla çalışma yapılabilir.

$\mathrm{Bu}$ araştırmada öğrenci görüşlerine dayalı başarıyı etkilediği öngörülen bazı değişkenler kullanılmıştır. Modele alınmayan diğer değişkenlerin de (matematiğe karşı tutum, ölçme ve değerlendirme dersi kaygı düzeyi, cinsiyet, özyeterlilik, özgüven, ilgi düzeyi vb.) kullanılması ve bölümlere göre sayısal, sözel ve eşit ağırlıklı alanlarda eğitim görenler arasında farklılık olup olmadığını tespit etmek üzere araştırma yapılabilir.

\section{KAYNAKÇA}

Aktaş, M. ve Alıcı, D. (2012). Eğitimde ölçme ve değerlendirme dersine yönelik tutum ölçeğinin (EÖD-TÖ) geliştirilmesi. Journal of Qafqaz University, Philology and Pedagogy, 33, 66-73.

Alkharusi, H., Kazem, A.M. \& Al Musawai, A. (2011). Knowledge, skills and attitudes of preservice and inservice teachers in educational measurement. Asia-Pasific Journal of Teacher Education, 39(2), 113123.

Baldemir, E., Özkoç, H. ve İşçi, Ö. (2009). MIMIC model ve yolsuzluk üzerine Türkiye uygulaması. Dokuz Eylül Üniversitesi İktisadi ve İdari Bilimler Fakültesi Dergisi, 24(2), 49-63.

Brown, T. A. (2015). Confirmatory factor analysis for applied research. Guilford Publications.

Çokluk, Ö., Şekercioğlu, G. ve Büyüköztürk, Ş. (2014). Sosyal bilimler için çok değişkenli istatistik: SPSS ve LISREL uygulamaları. (3.baskı) Ankara: Pegem Akademi Yayınları.

Erden, M. ve Akgül, S. (2010). İlköğretim öğrencilerinin matematik kaygısının ve öğretmen sosyal desteğinin matematik başarılarını yordama gücü. Eğitimde Kuram ve Uygulama, 6(1), 3-16.

Erdoğdu, M. Y. (2010). Öğretmenlerin ölçme ve değerlendirmeye yönelik tutumlarının bazı değişkenler açısından Incelenmesi. International Conference on New Trends in Education and Their Implications. Antalya, 11-13 November.

Kalender, Ö. M. (2010). The roles of affective, socioeconomic status and school factors on mathematics achievement: a structural equation modeling study. Yayımlanmamış Doktora Tezi. Ortadoğu Teknik Üniversitesi, Ankara. 
Kart, A. (2012). Demografik ve duyuşsal değişkenlerin ölçme ve değerlendirme dersi başarısını ve genel akademik başarıyı yordama gücü. Yayımlanmamış Yüksek Lisans Tezi. Ankara Üniversitesi, Eğitim Bilimleri Enstitüsü, Ankara.

Kesiktaş, A. D. (2006). Ders çalışma becerileri ve özel gereksinimli öğrenciler. Ankara Üniversitesi Ĕgitim Bilimleri Fakültesi Özel Ĕ̆itim Dergisi 2006, 7(1), 37-48.

Kline, R. B. (2005). Principles and practice of structural equation modelling. (2nd Edition). New York: Guilford Publications, Inc.,

Kline, R. B. (2015). Principles and practice of structural equation modeling. (4th edition). Guilford publications.

Özer, Y. ve Anıl, D. (2011). Öğrencilerin fen ve matematik başarılarını etkileyen faktörlerin yapısal eşitlik modeli ile incelenmesi. Hacettepe Üniversitesi Eğitim Fakültesi Dergisi, 41, 313-324.

Peker, M. ve Şentürk, B. (2012). İlköğretim beşinci sınıf öğrencilerinin matematik kaygılarının bazı değişkenler açısından incelenmesi. Dumlupınar Üniversitesi Sosyal Bilimler Dergisi, 34, 21-32.

Poyraz, S. (2012). İlköğretim ikinci kademe ögrencilerinde sınav kaygısı, matematik kaygısı, genel başarı ve matematik başarısı arasındaki ilişkilerin incelenmesi. Yayımlanmamış Yüksek Lisans Tezi. İstanbul Üniversitesi, İstanbul.

Reçber, Ş. (2011). An investigation of the relationship among the seventh grade students' mathematics self efficacy, mathematics anxiety, attitudes towards mathematics and mathematics achievement regarding gender and school type. Yayımlanmamış Yüksek Lisans Tezi. Ortadoğu Teknik Üniversitesi, Ankara.

Savaş, E., Taş, S. ve Duru, A. (2010). Factors affecting students‘ achievement in mathematics. Inönü Üniversitesi Ĕ̈itim Fakültesi Dergisi, 11(1), 113-132.

Süral, S. (2014). Eğitim fakültesi öğrencileri ile pedagojik formasyon alan öğrencilerin ölçme değerlendirme dersine yönelik tutumlarının incelenmesi. Adnan Menderes Üniversitesi, Sosyal Bilimler Enstitüsü Dergisi, 1( 3), 63-75.

Şimşek, O. F. (2007). Yapısal eşitlik modellemesine giriş (Temel ilkeler ve LISREL uygulamalarl). Ankara: Ekinoks.

Tağ, Ş. (2000). Reciprocal relationship between attitudes toward mathematics and achievement in mathematics. Unpublished Master' Thesis. Middle East Technical University, Ankara.

Taningco, M. T. V. (2006). Assessing the effects of parental decisions about school type and involvement on early elementary [Çevrim-içi: http://www.rand.org/content/dam/rand/pubs/rgs_dissertations/2006/RAND_RGSD205.pdf, Erişim tarihi: 25 Kasim 2015.]

Wang, J. \& Wang, X. (2012). Structural equation modeling applications using mplus. United Kingdom: Higher Education Press.

Yaşar, M. (2014). Eğitimde ölçme değerlendirme dersine yönelik tutum ölçeğinin geliştirilmesi. Ĕgitim Bilimleri Araştırma Dergisi. 4(1), 259-279.

Yavuz, M. (2009). Ortaöğretim kurumları öğrenci seçme ve yerleştirme sınavında öğrencilerin matematik- fen (mf) puanlarını etkilediği düşünülen bazı faktörlerin yapısal eşitlik modeli ile incelenmesi. Kuram ve Uygulamada Ĕgitim Bilimleri / Educational Sciences: Theory \& Practice, 9(3), 1557-1572.

Yenilmez, K. ve Duman, A. (2008). İlköğretimde matematik başarısını etkileyen faktörlere ilişkin öğrenci görüşleri. Sosyal Bilimler Dergisi, 19, 251-268.

Yılmaz, V. ve Çelik, H. E. (2013). Lisrel 9.1 ile yapısal eşitlik modellemesi: Temel kavramlar, uygulamalar, programlama. (Yenilenmiş 2. Baskı). Ankara: Anı Yayıncılık.

\section{EXTENDED ABSTRACT}

\section{Introduction}

Teacher candidates take educational measurement and evaluation (EME) course in their undergraduate education and it is important for them to successfully complete the course in order to be competent in their future occupation. Therefore, it is important to identify the variables that are affecting teacher candidates' achievement levels at educational measurement and evaluation course. When the studies conducted in the field of educational measurement and evaluation are examined it was found that they are mostly concerned with the competencies of teachers for measurement and evaluation and their attitudes towards the course. On the other hand, when studies related to general academic achievement are examined, it was found that variables such as department, gender, socioeconomic level, self-efficacy, anxiety and attitudes of the students have an effect on overall 
academic achievement (Poyraz, 2012; Kart, 2012; Süral, 2014). Parental education level, monthly income, school type and gender variables as well as general academic achievement level, mathanxiety and attitude toward the course were found as effective variables in mathematics education (Yenilmez and Duman, 2008, Erden and Akgül, 2010; Rescher, 2011, Peker and Senturk, 2012). In addition, it has been observed that the time allocated for studying affects the course achievement level positively and high socioeconomic level has an effect on students' general academic achievemnt in science and mathematics lessons (Anıl ve Özer, 2011; Kalender, 2010; Savaş, Taş and Duru, 2010; Yavuz, 2009; Duru, 2010).

The aim of this study is to investigate the relationship among the prospective teachers' achievement levels in educational measurement and evaluation (EME) course and some demographic and affective variables. In the study, the relations among the socioeconomic status, being graduate of Anatolian teacher education high school, study time, attitudes towards the EME course, mathematics anxiety, mathematics achievement level, general academic achievement and the measurement and evaluation course achievement level were investigated. This study is guided by the following research problem:

What is the level of relationship among the teacher candidates' achievement levels of the EME course, socioeconomic status, being graduate of Anatolian teacher education high school, attitude towards the course, study time, general academic achievement, mathematics achievement level and math anxiety?

\section{Method}

The study group consists of 443 prospective teachers who are students at the university in middle Anatolia in 2015 fall and 2016 semesters. The data in the study were obtained by measurement instrument which has three parts. The first part of the instrument consists of 9 items that include the demographic information about parental education and income levels, whether the students graduated from Anatolian teacher education high school, departments, study time, EME course grade, general academic achievement grade, mathematics achievement level. The second part of the instrument included, 9-item scale to measure math anxiety and the third part included "Attitudes Toward Educational Measurement and Evaluation scale" developed by Aktaş and Buyer (2012).

In this study, descriptive statistics related to mathematics achievement levels, general academic achievement grades, achievement grades in educational measurement and evaluation course, attitudes towards the course and mathematics anxiety levels were calculated. In order to answer the research problem, multiple indicators multiple causes (MIMIC) method was used. MIMIC models can be described as a sub-component of the structural equation model. MIMIC model is consisted of measurement model and structural model as in SEM analysis. The measurement model links latent variables to observed variables, and shows how the observed variables are defined by the latent variable. The structural model determines the relationship among latent variables and independent indicator variables (Baldemir, Özkoç and İşçi, 2009). In the study, the robust maximum likelihood (MLR) method was used to test the measurement model and structural models. MLR is a standard error-tolerant method that can be used in models consisting of categorical and continuous data, and with missing data (Wang and Wang, 2012).

In this study as a first step of the MIMIC analysis, measurement model was analyzed. After that, the structural model was constructed with the following specifications,

a. Effect of ANXIETY and SES latent variables to ATTITUDE latent variable,

b. Effect of ATTITUDE, ANXIETY and SES latent variables to MATHEMATICS latent variable,

c. Effect of ATTITUDE, ANXIETY, SES and MATHEMATICS latent variables to ACADEMIC latent variable, 


\section{d. Effect of ATTITUDE, ANXIETY, SES, MATHEMATICS and ACADEMIC latent variables to MEASUREMENT latent variable,}

e. Structural relations of whether TIME indicator variable has an effect on ATTITUDE and MEASUREMENT the latent variables and whether AOL indicator variable has an effect on ATTITUDE, MEASUREMENT, MATHEMATICS and ACADEMIC are examined by MIMIC models.

\section{Conclusion and Discussion}

According to the findings, the measurement and the structural models showed good fit statistics. Following these findings, the structural relationships between latent variables and indicator variables are examined in more detail below.

According to the results, when the structural model is examined, it is seen that the study time indicator variable explains the attitude latent variable more than other variables. Mathematics anxiety and being Anatolian teacher high school graduate status have a negative effect on the attitude toward EME course and the effects were not significant statistically.

When the variables that predict mathematic achievement are examined, it is found that mathematics anxiety explained most of the variance in mathematics achievement. In other words, as the mathematical anxiety increases, the achievement decreases. Moreover, attitude toward EME course did not have a significant effect on mathematics achievement. In addition, there was a statistically insignificant effect of socioeconomic status and being Anatolian teacher education high school on mathematics achievement.

When the variables that predict general academic achievement were examined, it was seen that mathematics was the most important factor explaining the academic achievement and the mathematics anxiety variable also affected the overall academic achievement positively. In other words, the general academic achievement of teacher candidates increases with mathematics anxiety. This is quite interesting. Despite the fact that the mathematics achievement grades of teacher candidates with low mathematics anxiety are high, it is expected that general academic achievements will show a similar tendency with mathematics achievement. The prospective teachers who are graduated from Anatolian teacher education high school had higher general academic grades compared to the prospective teachers who graduated from other schools. Another factor affecting general academic achievement is attitude towards EME course. Candidates with high attitude scores have high academic achievement grades, and those with low attitude scores have low academic achievement grades. Among the demographic variables socioeconomic status did not have a significant effect on general academic achievement.

Finally, it is observed that the highest factor explaining the achievement level in EME course is the general academic achievement variable. Teacher candidates with a high level of academic achievement in general have higher success in EME course. Another factor affecting the achievement level in the EME course is the attitude towards measurement and evaluation course. Being graduate of Anatolian teacher education high school also had positive effect on achievement of EME course compared to being graduate of other school types. Socioeconomic status did not have a significant effect on the achievement level for the EME course. It is also found that mathematics achievement and mathematics anxiety factors did not have a significant influence on the achievement in EME course. Although study time did not have statistically significant direct effect on the achievement in EME course, it had an indirect positive effect. 